IOS Press

\title{
Improved color and anthocyanin retention in strawberry puree by oxygen exclusion
}

\author{
Luke R. Howard*, Cindi Brownmiller and Ronald L. Prior \\ University of Arkansas, Department of Food Science, Fayetteville, AR, USA
}

Submitted 19 November 2013; accepted 19 December 2013

\begin{abstract}
.
BACKGROUND: Strawberry puree color is unstable during processing and storage due to oxidative reactions.

OBJECTIVE: To determine if strawberry puree prepared under nitrogen or carbon dioxide would result in greater retention of color and anthocyanins than samples prepared under air.

METHODS: Purees prepared under carbon dioxide, nitrogen or air were pasteurized and stored at $25^{\circ} \mathrm{C}$. Samples were evaluated one day, and at two week interval for eight weeks after processing for color ( $\mathrm{L}^{*}$, chroma and hue), anthocyanin content and percent polymeric color.

RESULTS: Purees prepared under carbon dioxide or nitrogen retained more anthocyanins ( $75 \%$ and $82 \%$, respectively) following pasteurization than samples prepared under air $(60 \%$ and $72 \%)$, respectively. The protective effect of oxygen exclusion on anthocyanin stability persisted throughout eight weeks of storage at $25^{\circ} \mathrm{C}$ with purees prepared under carbon dioxide or nitrogen each showing $23 \%$ retention, while purees prepared under air showed only $7 \%$ and $10 \%$ retention. Purees prepared under carbon dioxide or nitrogen also had greater color stability evident by lower $\mathrm{L}^{*}$, hue and percent polymeric color and greater chroma values than puree processed under air over storage.

CONCLUSIONS: Strict oxygen exclusion during strawberry processing appears to be a viable technology to improve anthocyanin and color stability, but additional technologies are needed to prevent anthocyanin losses that occur under anaerobic conditions during storage.
\end{abstract}

Keywords: Anthocyanin, color, oxygen exclusion, puree, storage, strawberry

\section{Introduction}

The attractive red color of strawberries is due to elevated levels of anthocyanin pigments, primarily pelargonidin derivatives. Unfortunately, color deterioration coincides with anthocyanin losses when strawberries are processed into preserves and jams [1, 2], juices [3-5], and purees [3-8], and these detrimental changes persist during storage of strawberry products at ambient temperature. Color instability in strawberry products has also been attributed to enzymatic browning, Maillard browning, ascorbic acid catalyzed degradation, and polymerization reactions of anthocyanins with other phenolics [9]. Among these factors, the roles of ascorbic acid and polyphenol oxidase (PPO) in catalyzing color deterioration and anthocyanin losses have received much attention. It has been known for some time that ascorbic acid plays an important role in the destruction of anthocyanins [10, 11]. Oxidation of ascorbic acid results in generation of free radicals, which can cleave the pyrilium ring of anthocyanins [12]. It has also been postulated that ascorbic acid can condense with anthocyanins at position 4 leading to loss of the flavylium pigmentation [13]. Ascorbic acid catalyzed destruction of anthocyanins can occur under both aerobic and anaerobic conditions [9]. Polyphenol oxidase can indirectly catalyze the destruction of anthocyanins, by oxidizing phenolics to quinones, which then react with anthocyanins to form brown condensation products [14]. Strawberry PPO is reported to be

*Corresponding author: Dr. Luke R. Howard, Department of Food Science, University of Arkansas, 2650N. Young Avenue, Fayetteville, AR 72704, USA. Tel.: +1 479575 2978; Fax: +1 479575 6936; E-mail: lukeh@uark.edu. 
highly resistant to both thermal and high pressure inactivation [15], and addition of an enzyme inhibitor to strawberry nectar made from puree resulted in excellent color stability during storage, supporting the role of oxidative enzymes in color degradation [16]. Since oxygen plays a critical role in the oxidation of ascorbic acid and PPO activity, strict oxygen exclusion throughout strawberry processing and storage may be a viable technology to improve color and anthocyanin stability. Bakker et al. [3] reported that strawberry juice and puree processed under a nitrogen blanket had higher levels of anthocyanins after processing than samples prepared in air, but nitrogen processing did not influence the rate of anthocyanin loss over seven weeks of storage at $20^{\circ} \mathrm{C}$. In this study, samples were not exposed to nitrogen blanketing throughout each stage of processing, which may have allowed for some oxidation to occur. The objective of our study was to determine if total oxygen exclusion throughout processing and storage of strawberry puree could result in greater color and anthocyanin retention.

\section{Materials and methods}

\subsection{Plant material and puree preparation}

Fresh strawberries (cultivars unknown) were obtained from Sam's Club (Fayetteville, AR). Two lots of strawberries were used for the study. The first lot was used in experiment one to compare air verses carbon dioxide processing, and the second lot was used in experiment two to compare air verses nitrogen processing. Strawberries were decapped manually with a stainless steel knife prior to processing. For oxygen exclusion treatments, decapped strawberries were placed into a desiccator attached to a vacuum pump and deaerated under $20 \mathrm{in} \mathrm{Hg}$ for 10 min. The deaerated berries were transferred to a Labconco model 5000400 controlled glove box (Kansas City, MO, USA). Prior to sealing the chamber, a commercial household blender, $118 \mathrm{~mL}$ jam jars (Ball Corp., Westminster, CO, USA) heat treated lids, and a dry anaerobic indicator strip (Becton Dickinson and Company, Burlington, NC, USA) were placed into the glove box. In the first experiment the chamber was flushed with carbon dioxide gas until the detection strip indicated anaerobic conditions had been obtained evident by color change from blue to white after the addition of a few drops of water. At this time the desiccator was opened and the strawberries were pureed, filled into the glass jars and sealed with metal lids. In the second experiment puree processing was accomplished using the same protocol except the glove box was flushed with nitrogen gas. Control samples were processed in the same manner in the glove box under air with the door open. All samples were pasteurized in boiling water at $100^{\circ} \mathrm{C}$ for $10 \mathrm{~min}$ and then stored in the dark at $25^{\circ} \mathrm{C}$. Three jars of puree from each treatment, control (air), carbon dioxide and nitrogen were analyzed one day after processing and after 2, 4, 6 and 8 weeks of storage.

\subsection{Color measurement}

Puree color (L*, chroma, and hue angle) was measured using a CR-300 Chroma Meter (Minolta, Ramsey, NJ, USA). The instrument was calibrated with a white plate, $Y=93.9, \mathrm{x}=0.3132, \mathrm{y}=0.3323$, standard observer $2^{\circ}$ each day of use.

\subsection{Anthocyanin analysis}

\subsubsection{Extraction}

Anthocyanins were extracted by the method of Cho et al. [17]. Five grams of strawberry puree was homogenized with $20 \mathrm{~mL}$ of methanol/water/formic acid (MWF) (60:37:3 v/v/v) using a Euro Turax T19 Tissuemizer (TekmarDohrman Corp., Mason, OH, USA). The samples were then filtered through Miracloth (Calbiochem, La Jolla, CA, USA), the residue isolated, and the extraction repeated. The filtrates were adjusted to $100 \mathrm{~mL}$ with the MWF extraction solvent.

\subsubsection{HPLC and HPLC/MS analysis of anthocyanins}

Prior to HPLC analysis, $10 \mathrm{~mL}$ of the MWF extracts were dried using a SpeedVac concentrator (ThermoSavant, Holbrook, NY, USA), re-suspended in $2 \mathrm{~mL}$ of an aqueous $3 \%$ formic acid solution, and then passed through $0.45 \mu \mathrm{m}$ 
filters. Anthocyanins were separated on a Symmetry $\mathrm{C}_{18}$ column (Waters Corp, Milford, MA, USA) according to the method of Cho et al. [17]. Anthocyanin glycosides monitored at $520 \mathrm{~nm}$ were quantified as corresponding anthocyanin glucoside equivalents using external calibration curves of a mixture of anthocyanin glucoside standards purchased from Polyphenols Laboratories (Sandnes, Norway).The identification of anthocyanins was performed by HPLC-MS using the same HPLC conditions described above, except the HPLC system was interfaced to a Bruker Esquire LC/MS ion trap mass spectrometer (Billerica, MA). Mass spectral analysis was conducted in positive ion electrospray mode using conditions previously described in Cho et al. [17]. Results are expressed as mg of each anthocyanin glycoside per $100 \mathrm{~g}$ of fresh berry or puree.

\subsubsection{Percent polymeric color analysis}

Color density and percent polymeric color were analyzed using the method of Giusti and Wrolstad [18]. Color density was determined by diluting the extracts with water to give absorbance readings between 0.5 and 1.0 at $510 \mathrm{~nm}$ when measured by the diode array spectrophotometer. For polymeric color analysis, $0.2 \mathrm{~mL}$ of $0.90 \mathrm{M}$ potassium metabisulfite was added to $2.8 \mathrm{~mL}$ diluted sample to create a bisulfite bleached sample. A non-bleached control was prepared by adding $0.2 \mathrm{~mL}$ of deionized water to a $2.8 \mathrm{~mL}$ diluted sample. After equilibrating for $15 \mathrm{~min}$, samples were measured at 420,510 and $700 \mathrm{~nm}$ using the diode array spectrophotometer. Color density was calculated using the control sample according to the following formula:

$$
\text { Color density }=\left[\left(\mathrm{A}_{420 \mathrm{~nm}}-\mathrm{A}_{700 \mathrm{~nm}}\right)+\left(\mathrm{A}_{510 \mathrm{~nm}}-\mathrm{A}_{700 \mathrm{~nm}}\right)\right] \times \text { dilution factor }
$$

Polymeric color was calculated using the bisulfite-bleached sample as follows:

$$
\text { Polymeric color }=\left[\left(\mathrm{A}_{420 \mathrm{~nm}}-\mathrm{A}_{700 \mathrm{~nm}}\right)+\left(\mathrm{A}_{510 \mathrm{~nm}}-\mathrm{A}_{700 \mathrm{~nm}}\right)\right] \times \text { dilution factor }
$$

Percent polymeric color was calculated using the following formula:

$$
\% \text { Polymeric color }=(\text { polymeric color } / \text { color density }) \times 100
$$

\subsection{Statistical analysis}

Three jars of puree from each treatment were analyzed at each sampling time with results expressed as means \pm standard error. The effects of processing treatment and storage time on anthocyanins, percent polymeric color, $\mathrm{L}^{*}$, chroma and hue angle values were determined by two way analysis of variance (ANOVA) using JMP ${ }^{\circledR}$ 8.0 (Cary, NC, USA). Differences between means were determined using the Student's $t$-test $(\alpha=0.05)$. Correlations among all physical and chemical attributes were determined by Pearson's correlation test.

\section{Results and discussion}

\subsection{Color}

The three color attributes lightness $\left(\mathrm{L}^{*}\right)$, saturation (chroma) and hue angle of the processed strawberry purees are presented in Table 1. Processing strawberries into puree resulted in increased $\mathrm{L}^{*}$ values, except for puree prepared under carbon dioxide. Lightness values generally increased throughout storage in all samples regardless of treatment, indicating fading of color. The increase in lightness values during storage is consistent with previous results for stored strawberry puree $[8,19]$, which most likely reflects decolorization of anthocyanins. However, samples prepared under carbon dioxide had lower lightness values than control samples at each storage time, and samples prepared under nitrogen had lower lightness values than control samples after 2 and 4 weeks of storage. The results demonstrate that oxygen excluded purees retained a darker color during storage than purees processed under air atmosphere.

Saturation (chroma) values declined in response to processing and throughout storage in all samples indicating a shift from a vivid to more dull color. A similar decline in chroma values was observed in strawberry puree stored for 3 months at $20^{\circ} \mathrm{C}$ [19]. However, puree prepared under carbon dioxide and nitrogen had higher saturation values 
Table 1

Color of strawberry puree as affected by oxygen exclusion during processing and storage

\begin{tabular}{|c|c|c|c|c|}
\hline \multirow{3}{*}{ Storage time } & \multicolumn{4}{|c|}{ Treatment } \\
\hline & Control & Carbon Dioxide & Control & Nitrogen \\
\hline & \multicolumn{4}{|c|}{$\mathrm{L}^{*}$-value } \\
\hline Fresh & $37.1 \pm 0.3 \mathrm{e}$ & $37.1 \pm 0.3 \mathrm{c}$ & $35.2 \pm 0.5 \mathrm{~d}$ & $35.2 \pm 0.5 \mathrm{~d}$ \\
\hline 1 day & $39.6 \pm 0.2 \mathrm{~d}$ & $36.9 \pm 0.1 \mathrm{c}^{*}$ & $38.7 \pm 0.5 \mathrm{c}$ & $37.1 \pm 0.7 \mathrm{c}$ \\
\hline 2 weeks & $41.3 \pm 0.2 \mathrm{bc}$ & $39.1 \pm 0.4 \mathrm{~b}^{*}$ & $41.9 \pm 0.2 \mathrm{ab}$ & $38.3 \pm 0.4 b c^{\prime}$ \\
\hline 4 weeks & $42.5 \pm 0.6 b$ & $38.8 \pm 0.2 b^{*}$ & $40.5 \pm 0.6 b$ & $37.6 \pm 0.8 c^{*}$ \\
\hline 6 weeks & $40.5 \pm 0.6 \mathrm{~cd}$ & $38.7 \pm 0.3 b^{*}$ & $42.3 \pm 0.5 \mathrm{a}$ & $41.4 \pm 0.4 \mathrm{a}$ \\
\hline \multirow[t]{2}{*}{8 weeks } & $44.9 \pm 0.5 \mathrm{a}$ & $41.4 \pm 0.1 \mathrm{a}^{*}$ & $38.9 \pm 0.6 \mathrm{c}$ & $39.5 \pm 0.6 \mathrm{~b}$ \\
\hline & \multicolumn{4}{|c|}{ Chroma } \\
\hline Fresh & $25.2 \pm 0.2 \mathrm{a}$ & $25.2 \pm 0.2 \mathrm{a}$ & $27.6 \pm 0.5 \mathrm{a}$ & $27.6 \pm 0.5 \mathrm{a}$ \\
\hline 1 day & $22.9 \pm 0.3 b$ & $23.5 \pm 0.7 b$ & $25.3 \pm 0.5 b$ & $26.5 \pm 0.2 \mathrm{ab}$ \\
\hline 2 weeks & $18.4 \pm 0.2 \mathrm{c}$ & $22.6 \pm 0.5 b c^{*}$ & $20.1 \pm 0.1 \mathrm{c}$ & $26.3 \pm 0.1 b^{*}$ \\
\hline 4 weeks & $16.9 \pm 0.1 \mathrm{de}$ & $23.7 \pm 0.5 b^{*}$ & $16.7 \pm 0.6 \mathrm{~d}$ & $23.3 \pm 0.2 c^{*}$ \\
\hline 6 weeks & $16.2 \pm 0.2 \mathrm{e}$ & $21.4 \pm 0.1 \mathrm{~cd}^{*}$ & $17.6 \pm 0.3 \mathrm{~d}$ & $22.5 \pm 0.5 c^{*}$ \\
\hline \multirow[t]{2}{*}{8 weeks } & $17.3 \pm 0.3 \mathrm{~d}$ & $20.7 \pm 0.13 \mathrm{~d}^{*}$ & $16.3 \pm 0.4 \mathrm{~d}$ & $21.1 \pm 0.4 \mathrm{~d}^{*}$ \\
\hline & \multicolumn{4}{|c|}{ Hue } \\
\hline Fresh & $24.1 \pm 0.4 \mathrm{e}$ & $24.1 \pm 0.4 \mathrm{f}$ & $24.6 \pm 0.5 f$ & $24.6 \pm 0.5 f$ \\
\hline 1 day & $25.8 \pm 0.2 \mathrm{e}$ & $25.3 \pm 0.4 \mathrm{e}$ & $26.9 \pm 0.5 \mathrm{e}$ & $27.7 \pm 0.1 \mathrm{e}$ \\
\hline 2 weeks & $34.3 \pm 0.3 \mathrm{~d}$ & $27.5 \pm 0.3 \mathrm{~d}^{*}$ & $34.9 \pm 0.3 \mathrm{~d}$ & $29.9 \pm 0.2 \mathrm{~d}^{*}$ \\
\hline 4 weeks & $43.6 \pm 0.1 \mathrm{c}$ & $29.9 \pm 0.1 \mathrm{c}^{*}$ & $52.5 \pm 0.8 \mathrm{c}$ & $33.2 \pm 0.6 \mathrm{c}^{*}$ \\
\hline 6 weeks & $52.7 \pm 0.9 b$ & $33.9 \pm 0.3 b^{*}$ & $57.9 \pm 0.9 b$ & $37.6 \pm 0.5 b^{*}$ \\
\hline 8 weeks & $58.9 \pm 1.3 \mathrm{a}$ & $37.3 \pm 0.3 \mathrm{a}^{*}$ & $61.0 \pm 0.3 \mathrm{a}$ & $42.9 \pm 0.8 \mathrm{a}^{*}$ \\
\hline
\end{tabular}

Note: Two different lots of strawberries were used in the experiments. The first lot was used in experiment one to compare control (air) verses carbon dioxide processing and the second lot was used in experiment two to compare control (air) verses nitrogen processing. Values are means \pm SE. Mean values within columns with different letters are significantly different $(P \leq 0.05)$. *denotes significant difference among control and carbon dioxide and nitrogen treated samples at each storage time.

than corresponding control samples after 2, 4, 6 and 8 weeks of storage, indicating that oxygen exclusion resulted in retention of a more vivid color throughout storage.

Hue values increased in all samples in response to processing and throughout storage indicating a color change from red to more orange. A similar marked increase in hue value was previously observed when strawberry puree was stored for 3 months at $20^{\circ} \mathrm{C}$ [19]. Puree prepared under carbon dioxide and nitrogen had lower hue values than corresponding control samples after $2,4,6$, and 8 weeks of storage. The hue values of the two control samples (58.9 and 61.0) after 8 weeks of storage reflect a yellow-orange color, whereas the hue values of the carbon dioxide (37.3) and nitrogen (42.9) prepared samples after 8 weeks of storage reflect a red-orange color. Considering all three color attributes, puree prepared under carbon dioxide and nitrogen retained a darker, more vivid red color than control puree over 8 weeks of storage.

\subsection{Total anthocyanins and percent polymeric color}

The total anthocyanin content of purees determined by the sum of individual anthocyanins quantified by HPLC, and percent polymeric color values are presented in Table 2. Levels of total anthocyanins declined precipitously in all samples over eight months of storage and purees processed under carbon dioxide or nitrogen had higher levels of total anthocyanins than corresponding control samples at each sampling time. Purees processed under carbon dioxide or nitrogen retained higher levels of total anthocyanins (75\% and $82 \%$, respectively) than corresponding 
Table 2

Percent polymeric color and total anthocyanin content (mg/100 $\mathrm{g} \mathrm{FW}$ ) of strawberry puree as affected by oxygen exclusion during processing and storage

\begin{tabular}{|c|c|c|c|c|}
\hline \multirow[b]{2}{*}{ Storage time } & \multicolumn{4}{|c|}{ Treatment } \\
\hline & Control & Carbon Dioxide & Control & Nitrogen \\
\hline & \multicolumn{4}{|c|}{$\%$ Polymeric color } \\
\hline Fresh & $5.0 \pm 0.8 \mathrm{~d}$ & $5.0 \pm 0.8 \mathrm{~d}$ & $6.8 \pm 0.8 \mathrm{~d}$ & $6.8 \pm 0.8 \mathrm{~d}$ \\
\hline 1 day & $6.0 \pm 0.2 \mathrm{~d}$ & $5.5 \pm 0.4 \mathrm{~d}$ & $10.2 \pm 0.1 \mathrm{~d}$ & $9.4 \pm 0.5 \mathrm{~d}$ \\
\hline 2 weeks & $17.5 \pm 0.8 \mathrm{c}$ & $13.0 \pm 1.6 \mathrm{c} *$ & $23.9 \pm 0.4 \mathrm{c}$ & $15.5 \pm 1.3 \mathrm{c}^{*}$ \\
\hline 4 weeks & $34.0 \pm 0.6 b$ & $19.3 \pm 1.0 b^{*}$ & $57.3 \pm 4.0 \mathrm{~b}$ & $30.9 \pm 1.3 b^{*}$ \\
\hline 6 weeks & $48.4 \pm 3.5 \mathrm{a}$ & $25.3 \pm 1.2 \mathrm{a}^{*}$ & $53.6 \pm 2.0 \mathrm{~b}$ & $28.6 \pm 1.5 b^{*}$ \\
\hline \multirow[t]{2}{*}{8 weeks } & $52.5 \pm 4.2 \mathrm{a}$ & $26.1 \pm 0.4 a^{*}$ & $65.9 \pm 3.1 \mathrm{a}$ & $39.7 \pm 2.5 \mathrm{a}^{*}$ \\
\hline & \multicolumn{4}{|c|}{ Total anthocyanins - HPLC } \\
\hline Fresh & $21.9 \pm 1.3 \mathrm{a}$ & $21.9 \pm 1.3 \mathrm{a}$ & $16.5 \pm 1.5 \mathrm{a}$ & $16.5 \pm 1.5 \mathrm{a}$ \\
\hline 1 day & $13.2 \pm 0.3 b(60)$ & $16.4 \pm 0.8 b^{*}(75)$ & $11.9 \pm 0.2 b(72)$ & $13.5 \pm 0.6 b *(82)$ \\
\hline 2 weeks & $5.7 \pm 0.1 \mathrm{c}(26)$ & $7.3 \pm 0.3 c^{*}(33)$ & $6.5 \pm 0.4 \mathrm{c}(39)$ & $12.3 \pm 0.9 b c *(74)$ \\
\hline 4 weeks & $3.9 \pm 0.8 \mathrm{~cd}(18)$ & $7.4 \pm 0.7 \mathrm{c} *(34)$ & $3.1 \pm 0.0 \mathrm{~d}(19)$ & $10.5 \pm 0.5 c^{*}(64)$ \\
\hline 6 weeks & $2.2 \pm 0.4 \mathrm{de}(10)$ & $5.1 \pm 0.1 c^{*}(23)$ & $2.7 \pm 0.1 \mathrm{~d}(16)$ & $7.0 \pm 0.3 \mathrm{~d}^{*}(42)$ \\
\hline 8 weeks & $1.6 \pm 0.1 \mathrm{e}(7)$ & $5.1 \pm 0.3 c^{*}(23)$ & $1.7 \pm 0.1 \mathrm{~d}(10)$ & $3.8 \pm 0.3 \mathrm{e}^{*}(23)$ \\
\hline
\end{tabular}

Note: Two different lots of strawberries were used in the experiments. The first lot was used in experiment one to compare control (air) verses carbon dioxide processing and the second lot was used in experiment two to compare control (air) verses nitrogen processing. Values are means \pm SE. Mean values within columns with different letters are significantly different $(P \leq 0.05)$. *denotes significant difference among control and carbon dioxide and nitrogen treated samples at each storage time. Values within parentheses indicate percent retention compared to fresh berries.

control samples $(60 \%$ and $72 \%$, respectively) one day after processing, and this effect persisted throughout storage. A previous study where strawberry puree was prepared under a nitrogen blanket also resulted in greater retention of total anthocyanins compared with puree prepared under air [3]. The percent retention of anthocyanins in control samples processed under air are similar to percent retention values of 72 to $79 \%$ previously reported for strawberry puree following pasteurization $[4,6,20]$. Anthocyanin losses in strawberry puree following pasteurization appear to be greatly influenced by genotype as puree produced from three different genotypes showed retention values of $123 \%$, $98 \%$ and $51 \%$ [5]. After eight weeks of storage, purees processed under carbon dioxide or nitrogen both retained $23 \%$ of the initial total anthocyanins, while corresponding control samples retained only $7 \%$ and $10 \%$, respectively. The percent retention of anthocyanins in control samples processed under air after 8 weeks of storage was similar to the $13 \%$ retention value reported for strawberry puree stored for eight weeks at $22^{\circ} \mathrm{C} \mathrm{[6].}$

Oxygen exclusion during processing clearly ameliorated losses of anthocyanins compared with purees processed under air, but anthocyanin losses still occurred over 8 weeks of storage at $25^{\circ} \mathrm{C}$. These findings are consistent with those of Bakker et al. [3] who reported that puree processed under a nitrogen blanket retained more anthocyanins after processing than puree prepared in air, but that anthocyanins degraded at a similar rate regardless of atmosphere treatment. The protective effect of oxygen exclusion during processing may be due to a number of factors. Strawberry anthocyanins are susceptible to degradation by polyphenol oxidase (PPO). Polyphenol oxidase catalyzes the oxidation of phenolic such as chlorogenic acid and catechin to quinones, which in turn react with anthocyanins to form dark condensation products [14]. A mechanism involving a reaction between a quinone and/or secondary products of oxidation formed from the quinone and anthocyanin has also been shown to cause degradation of pelargonidin 3-glucoside, the predominate anthocyanin in strawberries [21]. Strawberries are reported to contain a heat stable PPO that can survive time and temperature conditions well beyond those typically used for pasteurization [15, 19]. By addition of a broad spectrum enzyme inhibitor, Gossinger et al. [16] predicted that $80 \%$ of the color degradation in strawberry nectar prepared from puree was the result of enzyme activities. Ascorbic acid has long been known to play an important role in the destruction of anthocyanins, especially in the presence of oxygen and transition metals [10, 
22, 23]. Two potential mechanisms have been postulated for ascorbic acid catalyzed decolorization of anthocyanins. The first mechanism involves oxidation of ascorbic acid to produce free radicals, which cleave the pyrilium ring of anthocyanins [12], and the second one involves direct condensation of ascorbic acid at the 4-position of anthocyanins [13]. Additionally, ascorbic acid catalyzed decolorization of anthocyanins has been shown to proceed rapidly in both the presence and absence of oxygen [9]. Strict exclusion of oxygen during processing and storage would be expected to retard PPO activity and oxidation of ascorbic acid leading to greater retention of anthocyanins in purees processed under carbon dioxide and nitrogen. However, anthocyanins still declined markedly over eight weeks of storage in oxygen excluded purees, suggesting that anthocyanins are susceptible to degradation under anaerobic conditions. More research is needed to confirm if these losses are due to direct condensation of ascorbic acid with anthocyanins as proposed by Jurd [13], or another unknown mechanism.

Processing strawberries into puree had no effect on percent polymeric color values, but the values increased in all samples from one day to 8 weeks of storage. Similar increases in percent polymeric color was reported for strawberry puree stored at $20^{\circ} \mathrm{C}$ for 5 and 24 weeks [3,8]. Purees processed under carbon dioxide or nitrogen had lower polymeric color values than corresponding control samples at each sampling time. The lower polymeric color values in purees processed under carbon dioxide or nitrogen are consistent with greater retention of monomeric anthocyanins in the samples. Our results contrast with those of Bakker et al. [3] who found that strawberry puree prepared under a blanket of nitrogen had similar polymeric color values as puree processed under air over 5 weeks of storage at $20^{\circ} \mathrm{C}$. We suspect that the lower percent polymeric color values for oxygen excluded samples in our study may be due to stricter oxygen exclusion, since the fresh fruit were initially vacuum deaerated to remove intercellular gases and then transferred to a glove box where the fruit were processed under strictly controlled anaerobic conditions.

\subsection{Anthocyanin composition}

Representative HPLC chromatograms of the two lots of fresh strawberries used to prepare purees are shown in Fig. 1 and the anthocyanin composition of the purees determined by HPLC is shown in Table 3. Four anthocyanins, pelargonidin 3-glucoside $(\mathrm{m} / \mathrm{z} 433 / 271)$, pelargonidin 3-rutinoside $(\mathrm{m} / \mathrm{z} 579 / 433 / 271)$, pelargonidin 3-malonyl-glucoside $(\mathrm{m} / \mathrm{z}$ $519 / 433 / 271)$, and pelargonidin 3-acetyl-glucoside $(\mathrm{m} / \mathrm{z}$ 475/271) were detected in both lots of strawberries by HPLC and identified by HPLC-MS. The first lot of strawberries (Fig. 1A) used to compare air verses carbon dioxide treated purees also contained a small peak of cyanidin 3-glucoside $(\mathrm{m} / \mathrm{z} 449 / 287)$ that was not present in the second lot of strawberries (Fig. 1B). The results for cyanidin 3-glucoside are not presented in Table 3 since the compound was present at a low amount in fresh berries $(0.2 \mathrm{mg} / 100 \mathrm{~g} \mathrm{FW})$, and was non-detectible following pasteurization in air or carbon dioxide treated purees. Cyanidin 3-glucoside was also non-detectible following processing of strawberries into jam [24]. Pelargonidin 3-glucoside was the predominant anthocyanin in both lots of strawberries, accounting for $72 \%$ of total anthocyanins in the first lot of strawberries used to compare the air control verses carbon dioxide treated purees and $86 \%$ of total anthocyanins in the second lot of strawberries used to compare the air control verses nitrogen treated purees. Both lots of strawberries contained comparable levels of pelargonidin 3-rutinoside, but the first lot of strawberries contained a greater proportion of the two acylated anthocyanins, pelargonidin 3-malonyl-glucoside and pelargonidin 3-acetyl-glucoside than the second lot of strawberries. The anthocyanin composition of strawberries was consistent with previous studies $[6,25]$ with the exception of cyanidin 3-glucoside described above. All individual anthocyanins declined markedly throughout storage, but purees processed under carbon dioxide or nitrogen retained higher levels of each anthocyanin than purees processed under air at most sampling points. The two acylated anthocyanins, pelargonidin 3-malonyl-glucoside and pelargonidin 3-acetyl-glucoside were less stable during storage than pelargonidin 3-glucoside and pelargonidin 3-rutinoside. Several studies have reported pelargonidin 3-malonyl glucoside to be less stable than pelargonidin 3-glucoside during storage of strawberry puree at ambient temperature $[5,6,8,26]$.

\subsection{Correlations among anthocyanins and color attributes}

The correlations among total anthocyanins, percent polymeric color, and color attributes are shown in Table 4. All correlations presented are highly significant $(P<0.0001)$. Total anthocyanin results showed inverse correlations with percent polymeric color, $\mathrm{L}^{*}$ and hue values, and positive correlations with chroma values. Percent polymeric 

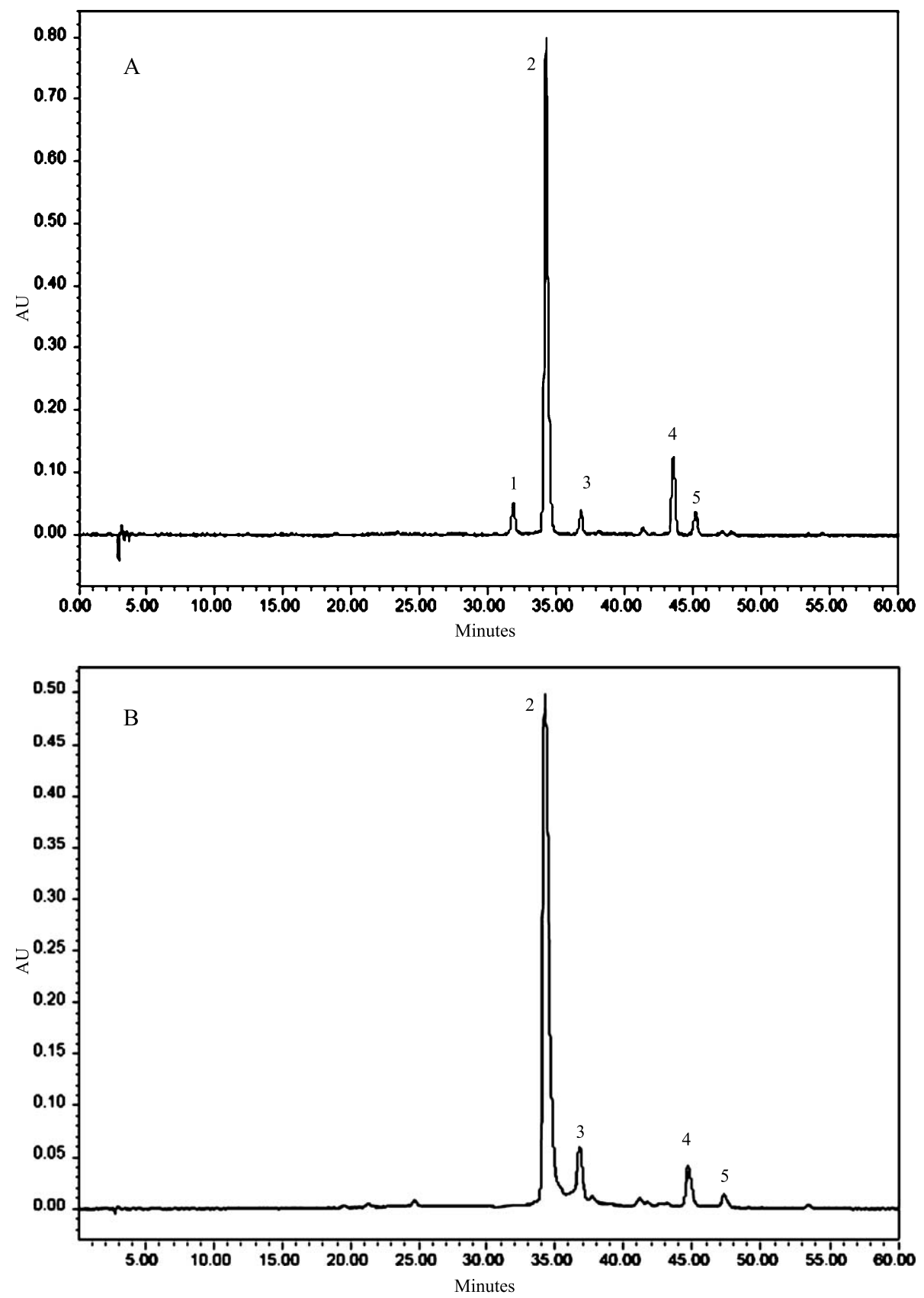

Fig. 1. HPLC chromatograms (Abs $520 \mathrm{~nm}$ ) of anthocyanins in fresh strawberries used to prepare purees in experiment one (A) and two (B). Peak 1 = cyanidin 3-glucoside, peak 2 = pelargonidin 3-glucoside, peak 3=pelargonidin 3-rutinoside, peak 4=pelargonidin 3-malonyl-glucoside, and peak $5=$ pelargonidin 3-acetyl-glucoside.

color values correlated inversely with chroma values and positively with $\mathrm{L}^{*}$ and hue values. The color of strawberry puree is highly associated with anthocyanin content, hence it is logical that anthocyanin loss during storage was accompanied by increased polymeric color, $\mathrm{L}^{*}$ and hue values, and decreased chroma values reflecting shift of a dark red color immediately after processing to a more light red-orange color after 8 weeks of storage. 
Table 3

Anthocyanin composition $(\mathrm{mg} / 100 \mathrm{~g})$ of strawberry puree as affected by oxygen exclusion during processing and storage

\begin{tabular}{|c|c|c|c|c|}
\hline \multirow{3}{*}{ Storage time } & \multicolumn{4}{|c|}{ Treatment } \\
\hline & Control & Carbon Dioxide & Control & Nitrogen \\
\hline & \multicolumn{4}{|c|}{ Pgd 3-glucoside } \\
\hline Fresh & $15.7 \pm 1.0 \mathrm{a}$ & $15.7 \pm 1.0 \mathrm{a}$ & $14.2 \pm 1.3 \mathrm{a}$ & $14.2 \pm 1.3 \mathrm{a}$ \\
\hline 1 day & $9.7 \pm 0.2 b(62)$ & $12.3 \pm 0.6 b^{*}(78)$ & $9.8 \pm 0.2 b(69)$ & $11.7 \pm 0.6 \mathrm{~b}(82)$ \\
\hline 2 weeks & $4.5 \pm 0.1 \mathrm{c}(29)$ & $5.6 \pm 0.3 c^{*}(36)$ & $5.6 \pm 0.3 \mathrm{c}(39)$ & $0.6 \pm 0.8 \mathrm{c} *(75)$ \\
\hline 4 weeks & $3.1 \pm 0.6 \mathrm{~cd}(20)$ & $6.0 \pm 0.6 \mathrm{~cd}^{*}(38)$ & $3.1 \pm 0.0 \mathrm{~d}(22)$ & $9.1 \pm 0.6 c^{*}(64)$ \\
\hline 6 weeks & $2.2 \pm 0.4 \mathrm{~d}(14)$ & $4.1 \pm 0.1 \mathrm{~cd}^{*}(26)$ & $2.7 \pm 0.1 \mathrm{~d}(19)$ & $6.2 \pm 0.3 \mathrm{~d}^{*}(44)$ \\
\hline \multirow[t]{2}{*}{8 weeks } & $1.6 \pm 0.1 \mathrm{~d}(10)$ & $4.4 \pm 0.3 \mathrm{~d}^{*}(23)$ & $1.7 \pm 0.1 \mathrm{~d}(12)$ & $3.3 \pm 0.2 \mathrm{e}^{*}(23)$ \\
\hline & \multicolumn{4}{|c|}{ Pgd 3-rutinoside } \\
\hline Fresh & $1.17 \pm 0.07 \mathrm{a}$ & $1.17 \pm 0.07 \mathrm{a}$ & $1.00 \pm 0.11 \mathrm{a}$ & $1.00 \pm 0.11 \mathrm{a}$ \\
\hline 1 day & $0.65 \pm 0.05 \mathrm{~b}(56)$ & $0.80 \pm 0.06 \mathrm{~b}(68)$ & $0.75 \pm 0.05 b(75)$ & $0.87 \pm 0.03 \mathrm{a}(87)$ \\
\hline 2 weeks & $0.30 \pm 0.00 \mathrm{c}(26)$ & $0.43 \pm 0.03 c^{*}(37)$ & $0.47 \pm 0.03 \mathrm{c}(47)$ & $0.83 \pm 0.07 \mathrm{a} *(83)$ \\
\hline 4 weeks & $0.23 \pm 0.03 \mathrm{c}(20)$ & $0.37 \pm 0.03 c^{*}(32)$ & NDd (0) & $0.97 \pm 0.07 \mathrm{a}^{*}(97)$ \\
\hline 6 weeks & NDd (0) & $0.33 \pm 0.03 c^{*}(28)$ & NDd (0) & $0.53 \pm 0.09 \mathrm{~b} *(53)$ \\
\hline \multirow[t]{2}{*}{8 weeks } & NDd (0) & $0.33 \pm 0.03 \mathrm{c}^{*}(28)$ & $\operatorname{NDd}(0)$ & $0.37 \pm 0.03 b^{*}(37)$ \\
\hline & \multicolumn{4}{|c|}{ Pgd 3-malonyl-glucoside } \\
\hline Fresh & $3.03 \pm 0.20 \mathrm{a}$ & $3.03 \pm 0.20 \mathrm{a}$ & $0.63 \pm 0.09 \mathrm{a}$ & $0.63 \pm 0.09 \mathrm{a}$ \\
\hline 1 day & $1.85 \pm 0.05 \mathrm{~b}(61)$ & $2.27 \pm 0.14 \mathrm{~b}(75)$ & $0.45 \pm 0.05 b(71)$ & $0.37 \pm 0.09 \mathrm{bc}(59)$ \\
\hline 2 weeks & $0.67 \pm 0.03 \mathrm{c}(22)$ & $0.83 \pm 0.03 \mathrm{c}^{*}(27)$ & $0.23 \pm 0.03 \mathrm{c}(37)$ & $0.40 \pm 0.06 b^{*}(63)$ \\
\hline 4 weeks & $0.40 \pm 0.10 \mathrm{c}(13)$ & $0.70 \pm 0.06 \mathrm{~cd}^{*}(23)$ & NDd (0) & $0.30 \pm 0.06 b^{*} *(48)$ \\
\hline 6 weeks & NDd (0) & $0.53 \pm 0.03 \mathrm{~cd}^{*}(17)$ & NDd (0) & $0.33 \pm 0.03 b c *(52)$ \\
\hline \multirow[t]{2}{*}{8 weeks } & NDd (0) & $0.47 \pm 0.07 \mathrm{~d}^{*}(16)$ & $\mathrm{NDd}(0)$ & $0.17 \pm 0.07 \mathrm{c}^{*}(27)$ \\
\hline & \multicolumn{4}{|c|}{ Pgd 3-acetyl-glucoside } \\
\hline Fresh & $2.07 \pm 0.09 \mathrm{a}$ & $2.07 \pm 0.09 \mathrm{a}$ & $0.67 \pm 0.07 \mathrm{a}$ & $0.67 \pm 0.07 \mathrm{a}$ \\
\hline 1 day & $1.00 \pm 0.00 \mathrm{~b}(48)$ & $1.00 \pm 0.06 \mathrm{~b}(48)$ & $0.55 \pm 0.05 \mathrm{a}(82)$ & $0.63 \pm 0.07 \mathrm{a}$ \\
\hline 2 weeks & $0.30 \pm 0.00 \mathrm{c}(14)$ & $0.43 \pm 0.03 c^{*}(21)$ & $0.20 \pm 0.06 \mathrm{~b}(30)$ & $0.40 \pm 0.06 \mathrm{~b} *(94)$ \\
\hline 4 weeks & $0.13 \pm 0.03 \mathrm{c}(6)$ & $0.30 \pm 0.00 \mathrm{~cd}^{*}(14)$ & NDc & $0.17 \pm 0.03 b c *(60)$ \\
\hline 6 weeks & $\mathrm{NDc}(0)$ & $0.17 \pm 0.03 \mathrm{~d}^{*}(8)$ & NDc & NDd (0) \\
\hline 8 weeks & NDc (0) & NDc (0) & NDc & NDd (0) \\
\hline
\end{tabular}

Note: Two different lots of strawberries were used in the experiments. The first lot was used in experiment one to compare control (air) verses carbon dioxide processing and the second lot was used in experiment two to compare control (air) verses nitrogen processing. Values are means $\pm \mathrm{SE}$. Mean values within columns with different letters are significantly different $(P \leq 0.05)$. ND $=$ non-detectible and $*$ denotes significant difference among control and carbon dioxide and nitrogen treated samples at each storage time. Values within parentheses indicate percent retention compared to fresh berries.

Table 4

Correlation coefficients among physical and chemical attributes. All correlations significant at $p<0.0001$

\begin{tabular}{|c|c|c|c|c|}
\hline & $\%$ polymeric color & $\mathrm{L}^{*}$-value & Chroma & Hue \\
\hline \multicolumn{5}{|l|}{$\%$ polymeric color } \\
\hline $\mathrm{L}^{*}$ value & 0.61 & & & \\
\hline Chroma & -0.83 & -0.74 & & \\
\hline Hue & 0.97 & 0.68 & -0.86 & \\
\hline Total anthocyanins & -0.79 & -0.73 & 0.81 & -0.81 \\
\hline
\end{tabular}




\section{Conclusions}

Processing strawberry puree under carbon dioxide or nitrogen atmosphere resulted in greater retention of anthocyanins compared to puree processed under air. Purees processed under carbon dioxide or nitrogen also retained more anthocyanins and had better color stability evident by lower $\mathrm{L}^{*}$, hue and percent polymeric color and greater chroma values than puree processed under air over eight weeks of storage at $25^{\circ} \mathrm{C}$. Strict oxygen exclusion during berry processing appears to be a viable technology to improve anthocyanin and color stability, but additional technologies are needed to prevent anthocyanin losses that occur under anaerobic conditions during storage.

\section{References}

[1] Abers JE, Wrolstad R. Causative factors of color deterioration in strawberry preserves during processing and storage. J Food Sci. 1979;44:7581.

[2] Patras A, Brunton NP, Tiwari BK. Stability and degradation kinetics of bioactive compounds and colour in strawberry jam during storage. Food Bioprocess Technol. 2011;4:1245-52.

[3] Bakker J, Bridle P, Koopman A. Strawberry juice colour: The effect of some processing variables on the stability of anthocyanins. J Sci Food Agric. 1992;60:471-6.

[4] Hartmann A, Patz C, Andlauer W, Dietrich H, Ludwig M. Influence of processing on quality parameters of strawberries. J Agric Food Chem. 2008;56:9484-9.

[5] Oszmianski J, Wojdylo A. Comparative study of phenolic content and antioxidant activity of strawberry puree, clear, and cloudy juices. Eur Food Res Technol. 2009;228:623-31.

[6] Aaby K, Wrolstad RE, Ekeberg D, Skrede G. Polyphenol composition and antioxidant activity in strawberry purees; impact of achene level and storage. J Agric Food Chem. 2007;55:5156-66.

[7] Patras A, Brunton NP, Da Pieve S, Butler F. Impact of high pressure processing on total antioxidant activity, phenolic, ascorbic acid, anthocyanin content and colour of strawberry and blackberry purees. Inn Food Sci Emerg Technol. 2009;10:308-13.

[8] Holzwarth M, Korhummel S, Carle R, Kammerer DR. Impact of enzymatic mash maceration and storage on anthocyanin and color retention of pasteurized strawberry purees. Eur Food Res Technol. 2012;234:207-22.

[9] Poei-Langston MS, Wrolstad RE. Color degradation in an ascorbic acid-anthocyanin-flavanol model system. J Food Sci. 1981;46: 1218-36.

[10] Sondheimer E, Kertesz ZI. Participation of ascorbic acid in the destruction of anthocynin in strawberry juice and model systems. New York State Agri Exper Stat Geneva, NY. 1953;992:475-9.

[11] Markakis P, Livingstone GE, Fillers GR. Quantitative aspects of strawberry pigment degradation. Food Res. 1957;22:117-33.

[12] Iacobucci GA, Sweeney JG. The chemistry of anthocyanins, anthocyanidins, and related flavylium salts. Tetrahedron. 1983;39:3005-38.

[13] Jurd L. Anthocyanin-type pigments. In: The chemistry of plant pigments. New York: Chichester, C.O. ed., Academic Press; 1972 . p. $123-42$.

[14] Kader F, Irmouli M, Zitouni N, Nicolas J, Metche M. Degradation of cyanidin 3-glucoside by caffeic acid $o$-quinone. Determination of the stoichiometry and characterization of the degradation products. J Agric Food Chem. 1999;47:4625-30.

[15] Terefe NS, Yang YH, Knoerzer K, Buckow R, Versteeg C. High pressure and thermal inactivation kinetics of polyphenol oxidase and peroxidase in strawberry puree. Inn Food Sci Emerg Technol. 2010;11:52-60.

[16] Gossinger M, Ullram T, Hermes M, Wendelin S, Berghold S, Halbwirth H, Stich, K, Berghofer E. Effects of pre-freezing, puree content and pasteurisation regime on colour stability of strawberry nectar made from puree. J Sci Food Agric. 2009;89:144-9.

[17] Cho MJ, Howard LR, Prior RL, Clark JR. Flavonoid glycosides and antioxidant capacity of various blackberry, blueberry, and red grape genotypes determined by high-performance liquid chromatography/mass spectrometry. J Sci Food Agric. 2004;84:1771-82.

[18] Giusti MM, Wrolstad RE. Characterization and measurement of anthocyanins with UV-visible spectroscopy. In: Wrolstad RE, editor. Current Protocols in Food Analytical Chemistry New York, NY: John Wiley \& Sons; 2001. p. F1.2.1-F1.2.13.

[19] Gossinger M, Moritz S, Hermes M, Wendelin S, Scherbichler H, Halbwirth H, Stich, K, Berghofer, E. Effects of processing parameters on colour stability of strawberry nectar from puree. J Food Eng. 2009;90:171-8.

[20] Patras A, Brunton NP, O'Donnell C, Tiwari BK. Effect of thermal processing on anthocyanin stability in foods; mechanisms and kinetics of degradation. Trends Food Sci Technol. 2010;21:3-8.

[21] Kader F, Irmouli M, Nicolas JP, Metche M. Proposed mechanism for the degradation of pelargonidin 3-glucoside by caffeic acid $o$-quinone. Food Chem. 2001;75:139-44.

[22] Timberlake CF. Metallic components of fruit juices. III. Oxidation and stability of ascorbic acid in model systems resembling blackcurrant juice. J Sci Food Agric. 1960;11:258-61.

[23] Timberlake CF. Metallic components of fruit juices. IV. Oxidation and stability of ascorbic acid in blackcurrant juice. J Sci Food Agric. 1960;11:268-73. 
[24] Amaro LF, Soares MT, Pinho C, Almeida IF, Ferreira IMPLVO, Pinho O. Influence of cultivar and storage conditions in anthocyanin content and radical scavenging activity of strawberry jams. World Acad Sci Eng Tech. 2012;69:118-22.

[25] Wu X, Prior RL. Systematic identification and characterization of anthocyanins by HPLC-ESI-MS/MS in common foods in the United States: Fruits and berries. J Agric Food Chem. 2005;53:2589-99.

[26] Aaby K, Ekeberg D, Skrede G. Characterization of phenolic compounds in strawberry (Fragaria $x$ ananassa) fruits by different HPLC detectors and contribution of individual compounds to total antioxidant capacity. J Agric Food Chem. 2007;55:4395-406. 